\title{
Cyanine Nanocage Activated by Near-IR Light for the Targeted Delivery of Cyclosporine A to Traumatic Brain Injury Sites
}

\author{
Caroline E. Black ${ }^{\#}$, Eugene Zhou ${ }^{+}$, Caitlin M. DeAngelo ${ }^{\#}$, Isaac Asante ${ }^{+}$, Rong Yang ${ }^{\#}$, Nicos A. Petasis ${ }^{*++}$, \\ Stan G. Louie*+\$ and Mark S. Humayun $* \$ \otimes$ \\ \#Department of Chemistry, University of Southern California, Los Angeles, California 90089, United States \\ ${ }^{+}$USC School of Pharmacy, University of Southern California, Los Angeles, California 90089, United States \\ tUSC Ginsburg Institute of Biomedical Therapeutics, Los Angeles, California 90033, United States \\ ${ }^{\otimes}$ Keck School of Medicine, Viterbi School of Engineering, and Roski Eye Institute, \\ University of Southern California, Los Angeles, California 90033, United States
}

\section{SUPPORTING INFORMATION - TABLE OF CONTENTS}

Experimental Procedures and NMR Data.......................................................................... 2

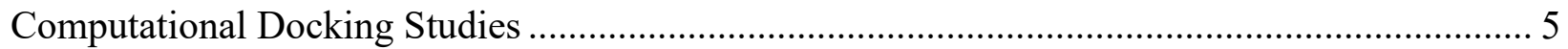

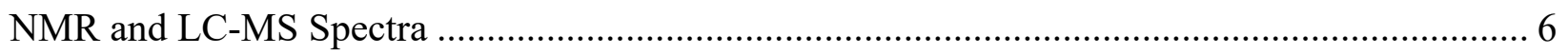

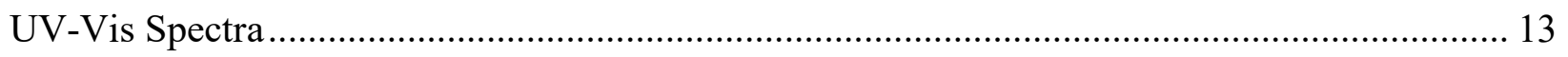

Determination of Molar Absorption Coefficients ............................................................... 16 


\section{Experimental Procedures and NMR Data}

General Materials and Methods: Unless otherwise stated, all reactions were conducted in oven-dried glassware under an atmosphere of argon using anhydrous solvents. All commercially obtained reagents (including compounds $\mathbf{1}$ and 2 ) were used as received. Flash chromatography was performed using Biotage SNAP Ultra C18 columns (12g and 30g) on the Biotage Isolera One instrument. LC-MS analyses were conducted on an Agilent 1260 Infinity ESI-MS using the following method: $30-100 \% \mathrm{MeCN}\left(90 \% \mathrm{MeCN}, 10 \% \mathrm{H}_{2} \mathrm{O}\right.$ ) in $\mathrm{H}_{2} \mathrm{O}$ with $0.1 \%$ formic acid, $0.300 \mathrm{~mL} / \mathrm{min}$, $14 \mathrm{~min}$. All NIR dye compounds were observed in the mass spectral data as the parent molecule without the $\mathrm{Na}^{+}$counterion. NMR spectra taken on Varian Mercury 400, 500 and $600 \mathrm{MHz}$ instruments. Chemical shifts reported as $\delta$ from $\mathrm{CDCl}_{3},\left(\mathrm{CD}_{3}\right)_{2} \mathrm{SO}_{\text {or }} \mathrm{CD}_{3} \mathrm{OD}$. NMR and LC/MS data were analyzed in MestReNova.

\section{Procedures for Synthesis of NIR Dyes}
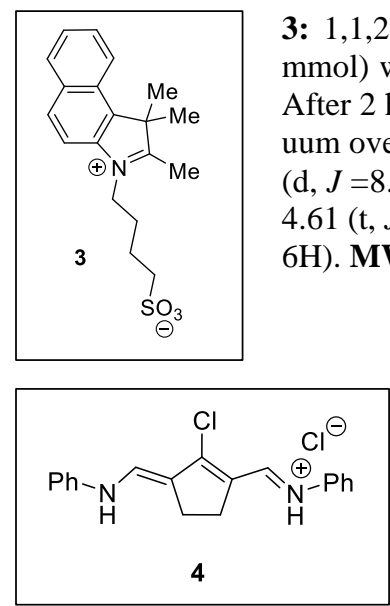

3: 1,1,2-trimethyl-1H-benzo[e]indole $(1.01 \mathrm{~g}, 4.83 \mathrm{mmol})$ and 1,4-butane sultone $(1.48 \mathrm{~mL}, 14.48$ $\mathrm{mmol}$ ) were added neat to a round-bottom flask at normal atmosphere, and stirred for $2 \mathrm{hr}$ at $120^{\circ} \mathrm{C}$. After $2 \mathrm{hr}$, the solid reaction mixture was washed thoroughly with acetone, filtered, and dried in a vacuum oven to afford the grey-blue solid product $(1.65 \mathrm{~g}, 99 \%) .{ }^{1} \mathbf{H} \mathbf{N M R}\left(\left(\mathrm{CD}_{3}\right)_{2} \mathrm{SO}, 600 \mathrm{MHz}\right): \delta 8.36$ $(\mathrm{d}, J=8.3 \mathrm{~Hz}, 1 \mathrm{H}), 8.28(\mathrm{~d}, J=8.9 \mathrm{~Hz}, 1 \mathrm{H}), 8.23-8.19(\mathrm{~m}, 2 \mathrm{H}), 7.80-7.76(\mathrm{~m}, 1 \mathrm{H}), 7.74-7.70(\mathrm{~m}, 1 \mathrm{H})$, $4.61(\mathrm{t}, J=7.9 \mathrm{~Hz}, 2 \mathrm{H}), 2.95(\mathrm{~s}, 3 \mathrm{H}), 2.54-2.52(\mathrm{~m}, 2 \mathrm{H}), 2.08-2.01(\mathrm{~m}, 2 \mathrm{H}), 1.81-1.76(\mathrm{~m}, 2 \mathrm{H}), 1.76(\mathrm{~s}$, 6H). MW: $345.46 \mathrm{~g} / \mathrm{mol}$. addition, the mixture was stirred at room temperature for $1 \mathrm{hr}$. DCM $(25 \mathrm{~mL})$ was added to the reaction mixture and let stand for a while. Finally, the solid was filtered, washed with acetone and $\mathrm{H}_{2} \mathrm{O}$, and dried overnight in a vacuum oven to afford the light purple solid $(6.44 \mathrm{~g}, 93 \%) .{ }^{1} \mathbf{H}$ NMR $\left(\left(\mathrm{CD}_{3}\right)_{2} \mathrm{SO}, 600 \mathrm{MHz}\right): \delta 8.31(\mathrm{~s}, 1 \mathrm{H}), 7.62(\mathrm{~d}, J=8.0 \mathrm{~Hz}, 2 \mathrm{H}), 7.57-7.40$ $(\mathrm{m}, 4 \mathrm{H}), 7.32-7.18(\mathrm{~m}, 4 \mathrm{H}), 6.91(\mathrm{~s}, 1 \mathrm{H}), 2.75(\mathrm{~s}, 4 \mathrm{H})$. $\mathbf{M W}$ (without $\mathrm{Cl}^{-}$anion): $309.82 \mathrm{~g} / \mathrm{mol}$.

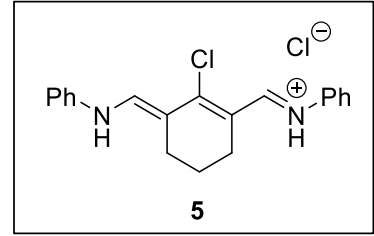
oven to yield a dark purple powdery solid (4.322g, 89\%). ${ }^{1} \mathbf{H}$ NMR (400 MHz, DMSO- $\left.d_{6}\right) \delta 8.54(\mathrm{~s}, 1 \mathrm{H}), 7.64-7.58(\mathrm{~m}$, $4 \mathrm{H}), 7.49-7.44(\mathrm{~m}, 4 \mathrm{H}), 7.35-7.25(\mathrm{~m}, 3 \mathrm{H}), 2.75(\mathrm{t}, J=6.2 \mathrm{~Hz}, 4 \mathrm{H}), 1.86(\mathrm{p}, J=6.1 \mathrm{~Hz}, 2 \mathrm{H})$. MW (without $\mathrm{Cl}^{-}$anion): $323.84 \mathrm{~g} / \mathrm{mol}$.

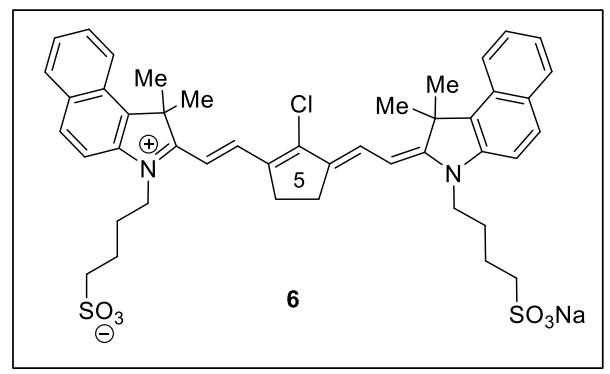

6: Indolenium salt 3 (1.50 g, $4.34 \mathrm{mmol})$ and dianiline 4 (0.5 g, $1.45 \mathrm{mmol})$ were dissolved in isopropyl alcohol $(7 \mathrm{~mL})$ in a round-bottom flask. To the reaction mixture was added triethylamine $(1.21 \mathrm{~mL})$ then acetic anhydride $(0.41 \mathrm{~mL})$. The reaction was stirred at $50{ }^{\circ} \mathrm{C}$ for $2 \mathrm{hr}$, while monitored by LC-MS. Upon completion, the reaction was cooled to room temperature, added to diethyl ether, and cooled at $2^{\circ} \mathrm{C}$ to afford crystallization of the product. Product was purified by recrystallization from $\mathrm{MeOH} / \mathrm{Et}_{2} \mathrm{O}$, followed by reverse-phase chromatography (30-100\% ACN in $\mathrm{H}_{2} \mathrm{O}$ ) to afford 6 as a green solid $(0.54 \mathrm{~g}, 45 \%)$. LC-MS analysis: $\lambda_{\max }=844 \mathrm{~nm}$, MS: $[\mathrm{M}+\mathrm{H}]$ 813; [M-H] 811 (MW of 6: $835.45 \mathrm{~g} / \mathrm{mol}) .{ }^{\mathbf{1}} \mathbf{H} \mathbf{N M R}\left(\left(\mathrm{CD}_{3}\right)_{2} \mathrm{SO}, 600\right.$ $\mathrm{MHz}): \delta 8.27(\mathrm{~d}, J=8.6 \mathrm{~Hz}, 2 \mathrm{H}), 8.09-8.05(\mathrm{~m}, 4 \mathrm{H}), 7.86(\mathrm{~d}, J=12.9 \mathrm{~Hz}, 2 \mathrm{H}), 7.80(\mathrm{~d}, J=8.8 \mathrm{~Hz}, 2 \mathrm{H}), 7.67-7.62(\mathrm{~m}, 2 \mathrm{H})$, 7.54-7.47 (m, 2H), $6.25(\mathrm{~d}, J=14.2 \mathrm{~Hz}, 2 \mathrm{H}), 4.33(\mathrm{t}, J=7.6 \mathrm{~Hz}, 4 \mathrm{H}), 3.15-3.05(\mathrm{~m}, 4 \mathrm{H}), 3.01(\mathrm{~s}, 4 \mathrm{H}), 1.94(\mathrm{~s}, 12 \mathrm{H}), 1.89$ (p, $J=7.8,7.4 \mathrm{~Hz}, 4 \mathrm{H}), 1.82-1.74(\mathrm{~m}, 4 \mathrm{H})$. 


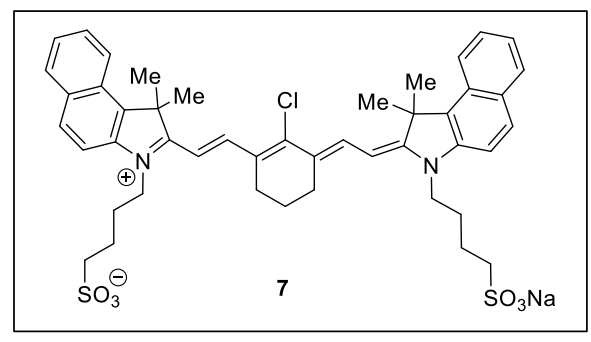
amount of DMF. The vial was filled with ethyl ether $(25 \mathrm{~mL})$ and cooled in a refrigerator overnight. The vial was rewarmed to room temperature, and the top ether layer was removed with a pipette while leaving the crystallized solid at the bottom of the container. More fresh ether was added to the container with the green solid, and the solid was allowed to settle to the bottom. The ether layer was removed again once the solid settled to the bottom of the container. Subsequent washing with ether and removal of the ether was performed until the ether layer is clear. The solid was dried under a constant stream of dry nitrogen to afford IR-820 as a dark green powdery solid $(0.396 \mathrm{~g}, 60 \%)$. Drying the solid was only performed directly before usage of the compound. The product was stored in an 8-dram vial filled with ether to separate the solid at the bottom from the moisture and oxygen in the air. LC/MS analysis: $\lambda_{\max }(820 \mathrm{~nm})$, observed $[\mathrm{M}+(-\mathrm{H})]=827[\mathrm{M}-(-\mathrm{H})]=825$. $(\mathrm{MW}$ of 7: $849.47 \mathrm{~g} / \mathrm{mol}) .{ }^{1} \mathbf{H}$ NMR $\left(500 \mathrm{MHz}, \mathrm{DMSO}-d_{6}\right) \delta 8.41-8.34(\mathrm{~m}, 2 \mathrm{H}), 8.30(\mathrm{~d}, J=8.7 \mathrm{~Hz}, 2 \mathrm{H}), 8.12-8.03(\mathrm{~m}, 4 \mathrm{H})$, $7.86(\mathrm{~d}, J=9.1 \mathrm{~Hz}, 2 \mathrm{H}), 7.68-7.62(\mathrm{~m}, 2 \mathrm{H}), 7.52(\mathrm{t}, J=8.4,6.9 \mathrm{~Hz}, 2 \mathrm{H}), 6.56(\mathrm{~d}, J=14.2 \mathrm{~Hz}, 2 \mathrm{H}), 4.51(\mathrm{t}, J=7.9 \mathrm{~Hz}$, $4 \mathrm{H}), 2.79(\mathrm{t}, J=6.3 \mathrm{~Hz}, 4 \mathrm{H}), 2.61(\mathrm{t}, J=6.7 \mathrm{~Hz}, 4 \mathrm{H}), 2.44-2.37(\mathrm{~m}, 2 \mathrm{H}), 2.13-2.03(\mathrm{~m}, 4 \mathrm{H}), 1.96(\mathrm{~s}, 12 \mathrm{H}), 1.91-1.72$ $(\mathrm{m}, 4 \mathrm{H})$.

\section{Procedures for Coupling of Linker to NIR Dyes}

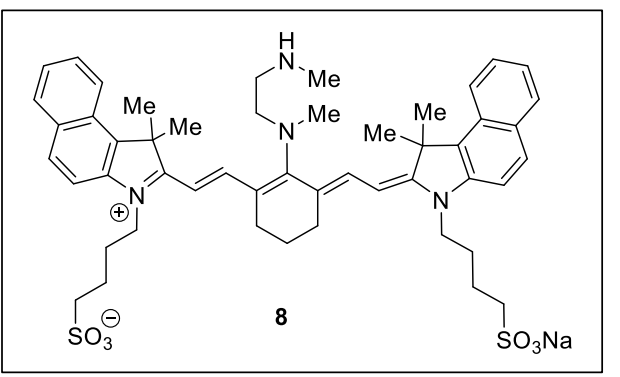

8: To a solution of 7 (0.0473 g, $0.0560 \mathrm{mmol})$ in DMF $(4 \mathrm{~mL})$ in an 8-dram vial was added $N, N^{\prime}$-Diisopropylethylamine $(0.030 \mathrm{~mL}, 0.167 \mathrm{mmol})$ and $N, N^{\prime}$-dimethyl ethylenediamine $(0.018 \mathrm{~mL}, 0.167 \mathrm{mmol})$. The reaction mixture was stirred at room temperature for 80 minutes, and the completion of reaction was confirmed by LC/MS. The reaction mixture was charged with approximately $25 \mathrm{~mL}$ of ethyl ether, filling the 8 -dram vial, and was cooled to $4^{\circ} \mathrm{C}$ for several hours. The vial was rewarmed to room temperature, and the top ether layer was removed with a pipette while leaving the crystallized solid at the bottom of the container. More fresh ether was added to the container with the blue solid, and the solid was allowed to settle to the bottom. The ether layer was removed again once the blue solid settled to the bottom of the container. Subsequent washing with ether and removal of the ether was performed until the ether layer is clear. The solid was dried under a constant stream of dry nitrogen to afford $\mathbf{8}$ as a dark blue solid $(0.039 \mathrm{~g}, 91 \%$, correcting for IR- 820 because it contains $80 \%$ dye). Drying the solid was only performed directly before usage of the compound. The product was stored in an 8-dram vial filled with ether to separate the blue solid at the bottom from the moisture and oxygen in the air. LC/MS analysis: $\lambda_{\max }(770 \mathrm{~nm})$, observed $[\mathrm{M}+(-\mathrm{H})]=879[\mathrm{M}-(-\mathrm{H})]=877$. $(\mathrm{MW}$ of $8: 901.17 \mathrm{~g} / \mathrm{mol})$.

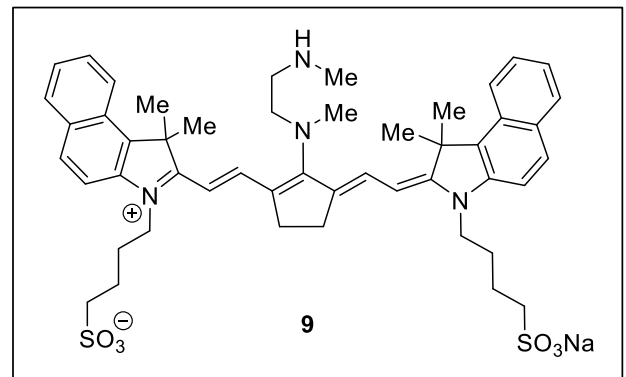

9: To a solution of $6(0.121 \mathrm{~g}, 0.145 \mathrm{mmol})$ in $\mathrm{DMF}(10 \mathrm{~mL})$ in an 8-dram vial under normal atmosphere was added N,N'-diisopropylethylamine $(0.076 \mathrm{~mL}, 0.434 \mathrm{mmol})$ and $\mathrm{N}, \mathrm{N}^{\prime}$-dimethyl ethylenediamine $(0.047 \mathrm{~mL}$, $0.434 \mathrm{mmol}$ ). The reaction mixture was stirred at room temperature for one hour, and LC-MS analysis confirmed the complete conversion of 6 to 9. Reaction mixture was added to ether and cooled at $2^{\circ} \mathrm{C}$ for several hours to afford crystallization of the product. The product was purified by washing with $3 \times 25 \mathrm{~mL}$ diethyl ether and removing the top ether layer from the solid after each wash. After the third wash, the solid was dried under a flow of $\mathrm{N}_{2}$ to afford 9 as a blue solid $(0.112 \mathrm{~g}, 88 \%)$. LC-MS analysis: $\lambda_{\max }=$ $738 \mathrm{~nm}, \mathrm{MS}:[\mathrm{M}+\mathrm{H}]$ 865; [M-H] 863 (MW of 9: $887.14 \mathrm{~g} / \mathrm{mol}$ ). ${ }^{1} \mathbf{H}$ NMR $\left(\left(\mathrm{CD}_{3}\right)_{2} \mathrm{SO}, 600 \mathrm{MHz}\right): \delta 8.15(\mathrm{~d}, J=8.7 \mathrm{~Hz}, 2 \mathrm{H}), 7.99(\mathrm{~d}, J=8.6 \mathrm{~Hz}, 4 \mathrm{H}), 7.88-7.84(\mathrm{~m}, 2 \mathrm{H}), 7.63(\mathrm{~d}, J=8.8 \mathrm{~Hz}, 2 \mathrm{H})$, 7.61-7.56 (m, 2H), 7.43-7.39 (m, 2H), $5.80(\mathrm{~d}, J=12.9 \mathrm{~Hz}, 2 \mathrm{H}), 4.18-4.12(\mathrm{~m}, 4 \mathrm{H}), 3.93-3.88(\mathrm{~m}, 3 \mathrm{H}), 3.07-3.01(\mathrm{~m}, 4 \mathrm{H})$, $2.86(\mathrm{~s}, 2 \mathrm{H}), 2.81-2.76(\mathrm{~m}, 4 \mathrm{H}), 2.56(\mathrm{~s}, 2 \mathrm{H}), 2.43(\mathrm{~s}, 3 \mathrm{H}), 1.88(\mathrm{~s}, 12 \mathrm{H}), 1.77-1.72(\mathrm{~m}, 8 \mathrm{H})$.

\section{Procedure for Synthesis of NIR Dye-Cyclosporine A Conjugates}



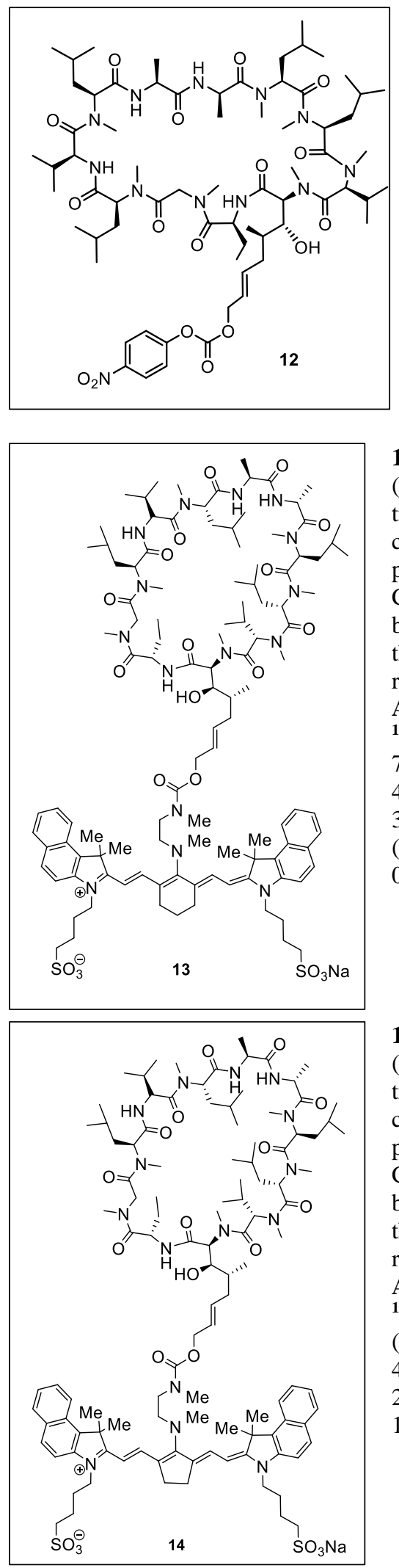

12: Cyclosporine A diol (2) $(0.051 \mathrm{~g}, 0.042 \mathrm{mmol})$, prepared from Cyclosporine A, was reacted with N,N'-diisopropylethylamine $(0.022 \mathrm{~mL}, 0.126 \mathrm{mmol})$ and 4 dimethylaminopyridine $(0.005 \mathrm{~g}, 0.0419 \mathrm{mmol})$ in a round-bottom flask dissolved in acetonitrile $(5 \mathrm{~mL})$. 4-Nitrophenyl chloroformate $(0.017 \mathrm{~g}, 0.084 \mathrm{mmol})$ in acetonitrile was added dropwise to the reaction over 10 minutes, and the mixture was stirred at room temperature for $3 \mathrm{hr}$, until LC-MS analysis confirmed the conversion of CsA diol $\mathbf{2}$ to the carbonate 12. Compound $\mathbf{1 2}$ was not isolated and was used in the next step without purification. (MW: $1383.74 \mathrm{~g} / \mathrm{mol}$; observed $\mathrm{M} / \mathrm{Z}=1384)$.
13: To the round-bottom containing CsA-carbonate 12 was added dye-linker 8 $(0.063 \mathrm{mmol})$ and 4-dimethylaminopyridine $(0.003 \mathrm{~g}, 0.021 \mathrm{mmol})$ both in acetonitrile. The reaction was heated to $40^{\circ} \mathrm{C}$ and stirred for $12-24 \mathrm{hr}$, until LC-MS analysis confirmed the complete consumption of $\mathbf{1 2}$ and formation of product 13. Upon completion, the reaction mixture was diluted with $25 \mathrm{~mL}$ of ethyl ether and cooled at $2^{\circ}$ $\mathrm{C}$ for several hours to afford crystallization of the product. The product was purified by first washing with $3 \times 25 \mathrm{~mL}$ diethyl ether and removing the top ether layer from the solid after each wash. Product was then purified by reverse-phase chromatography (40-100\% $\mathrm{ACN}$ in $\left.\mathrm{H}_{2} \mathrm{O}\right)$ to afford a deep blue solid (0.0052 g, 30\%). LC-MS Analysis: $\lambda_{\max }=738 \mathrm{~nm}$, MS: $[\mathrm{M}+\mathrm{H}] 1062(\mathrm{MW}+2 / 2)(\mathrm{MW}$ of 13: $2145.8 \mathrm{~g} / \mathrm{mol})$. ${ }^{1}$ H NMR $\left(600 \mathrm{MHz}, \mathrm{DMSO}-d_{6}\right) \delta 8.21-8.14(\mathrm{~m}, 2 \mathrm{H}), 8.03-7.97(\mathrm{~m}, 5 \mathrm{H}), 7.71-$ $7.62(\mathrm{~m}, 4 \mathrm{H}), 7.60-7.55(\mathrm{~m}, 2 \mathrm{H}), 7.45-7.40(\mathrm{~m}, 2 \mathrm{H}), 5.62(\mathrm{~d}, J=13.0 \mathrm{~Hz}, 1 \mathrm{H})$, $4.22-4.09(\mathrm{~m}, 4 \mathrm{H}), 3.99-3.89(\mathrm{~m}, 1 \mathrm{H}), 3.89-3.67(\mathrm{~m}, 3 \mathrm{H}), 3.66-3.42(\mathrm{~m}, 3 \mathrm{H})$, $3.40-3.35(\mathrm{~m}, 3 \mathrm{H}), 2.92-2.77(\mathrm{~m}, 16 \mathrm{H}), 2.77-2.68(\mathrm{~m}, 7 \mathrm{H}), 2.21(\mathrm{~s}, 3 \mathrm{H}), 1.90$ $(\mathrm{s}, 12 \mathrm{H}), 1.85-1.67(\mathrm{~m}, 22 \mathrm{H}), 1.64-1.24(\mathrm{~m}, 15 \mathrm{H}), 1.21-1.11(\mathrm{~m}, 7 \mathrm{H}), 0.93-$ $0.66(\mathrm{~m}, 44 \mathrm{H})$.

14: To the round-bottom containing CsA-carbonate 12 was added dye-linker 9 $(0.063 \mathrm{mmol})$ and 4-dimethylaminopyridine $(0.003 \mathrm{~g}, 0.021 \mathrm{mmol})$ both in acetonitrile. The reaction was heated to $40^{\circ} \mathrm{C}$ and stirred for $12-24 \mathrm{hr}$, until LC-MS analysis confirmed the complete consumption of $\mathbf{1 2}$ and formation of product 14. Upon completion, the reaction mixture was diluted with $25 \mathrm{~mL}$ of ethyl ether and cooled at $2^{\circ}$ $\mathrm{C}$ for several hours to afford crystallization of the product. The product was purified by first washing with $3 \times 25 \mathrm{~mL}$ diethyl ether and removing the top ether layer from the solid after each wash. Product was then purified by reverse-phase chromatography (40-100\% ACN in $\left.\mathrm{H}_{2} \mathrm{O}\right)$ to afford a deep blue solid $(0.014 \mathrm{~g}, 16 \%)$. LC-MS Analysis: $\lambda_{\max }=705 \mathrm{~nm}, \mathrm{MS}:[\mathrm{M}+\mathrm{H}] 1055(\mathrm{MW}+2 / 2)(\mathrm{MW}$ of 14: $2131.8 \mathrm{~g} / \mathrm{mol})$. ${ }^{1} \mathbf{H}$ NMR $\left(\mathrm{CD}_{3} \mathrm{OD}, 600 \mathrm{MHz}\right): \delta 8.20-8.11(\mathrm{~m}, 2 \mathrm{H}), 8.00-7.88(\mathrm{~m}, 6 \mathrm{H}), 7.59-7.47$ $(\mathrm{m}, 4 \mathrm{H}), 7.42-7.33(\mathrm{~m}, 2 \mathrm{H}), 5.86-5.73(\mathrm{~m}, 2 \mathrm{H}), 4.57(\mathrm{~s}, 2 \mathrm{H}), 4.48-4.36(\mathrm{~m}, 2 \mathrm{H}), 4.26-$ $4.07(\mathrm{~m}, 6 \mathrm{H}), 3.72(\mathrm{~s}, 3 \mathrm{H}), 3.22-2.76(\mathrm{~m}, 32 \mathrm{H}), 2.74-2.63(\mathrm{~m}, 3 \mathrm{H}), 2.12-1.85(\mathrm{~m}$, $26 \mathrm{H}), 1.70-1.58(\mathrm{~m}, 5 \mathrm{H}), 1.50-1.42(\mathrm{~m}, 3 \mathrm{H}), 1.41-1.36(\mathrm{~m}, 3 \mathrm{H}), 1.35-1.23(\mathrm{~m}, 13 \mathrm{H})$, $1.07-0.70(\mathrm{~m}, 51 \mathrm{H})$. 


\section{Computational Docking Studies}

A crystal structure of CsA in complex with the protein Cyclophilin A (CypA) (PDB ID: 1CWA) was used to dock both native CsA and synthetically modified CsA diol (2) in the CypA active site. Software PyRx was used for computational docking to determine optimal ligand conformations and binding affinity values. PyMol software was used to create figures to visualize top binding conformations of the ligands in CypA active site.

Table S1. Binding affinity values calculated in PyRx for CsA and CsA Diol in CypA active site (PDB ID: 1CWA).

\begin{tabular}{|c|c|c|c|}
\hline \multicolumn{1}{|c|}{ Ligand } & Binding Affinity & Ligand & $\begin{array}{c}\text { Binding } \\
\text { Affinity }\end{array}$ \\
\hline Cyclosporine A & -5.1 & CsA Diol 2 & -5.8 \\
\hline Cyclosporine A & -5.1 & CsA Diol 2 & -5.8 \\
\hline Cyclosporine A & -5 & CsA Diol 2 & -5.7 \\
\hline Cyclosporine A & -4.8 & CsA Diol 2 & -5.7 \\
\hline Cyclosporine A & -4.7 & CsA Diol 2 & -5.5 \\
\hline Cyclosporine A & -4.6 & CsA Diol 2 & -5.1 \\
\hline Cyclosporine A & -4.6 & CsA Diol 2 & -5.1 \\
\hline Cyclosporine A & -4.6 & CsA Diol 2 & -5.1 \\
\hline Cyclosporine A & -4.5 & CsA Diol 2 & -5 \\
\hline
\end{tabular}




\section{NMR and LC-MS Spectra}

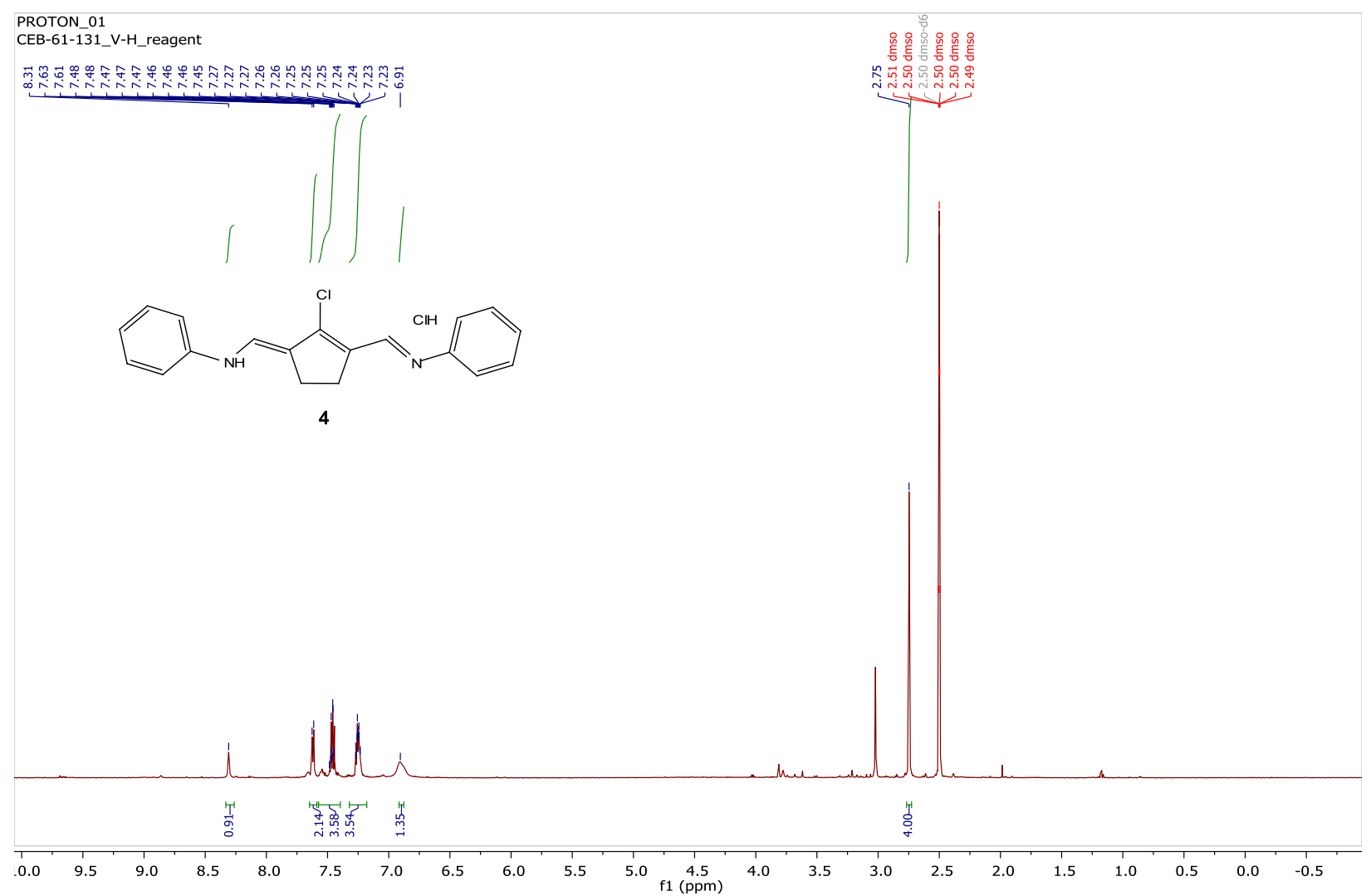

Figure S1. ${ }^{1} \mathrm{H}$ NMR spectrum of $4\left(\right.$ DMSO- $\left._{6}\right)$. 


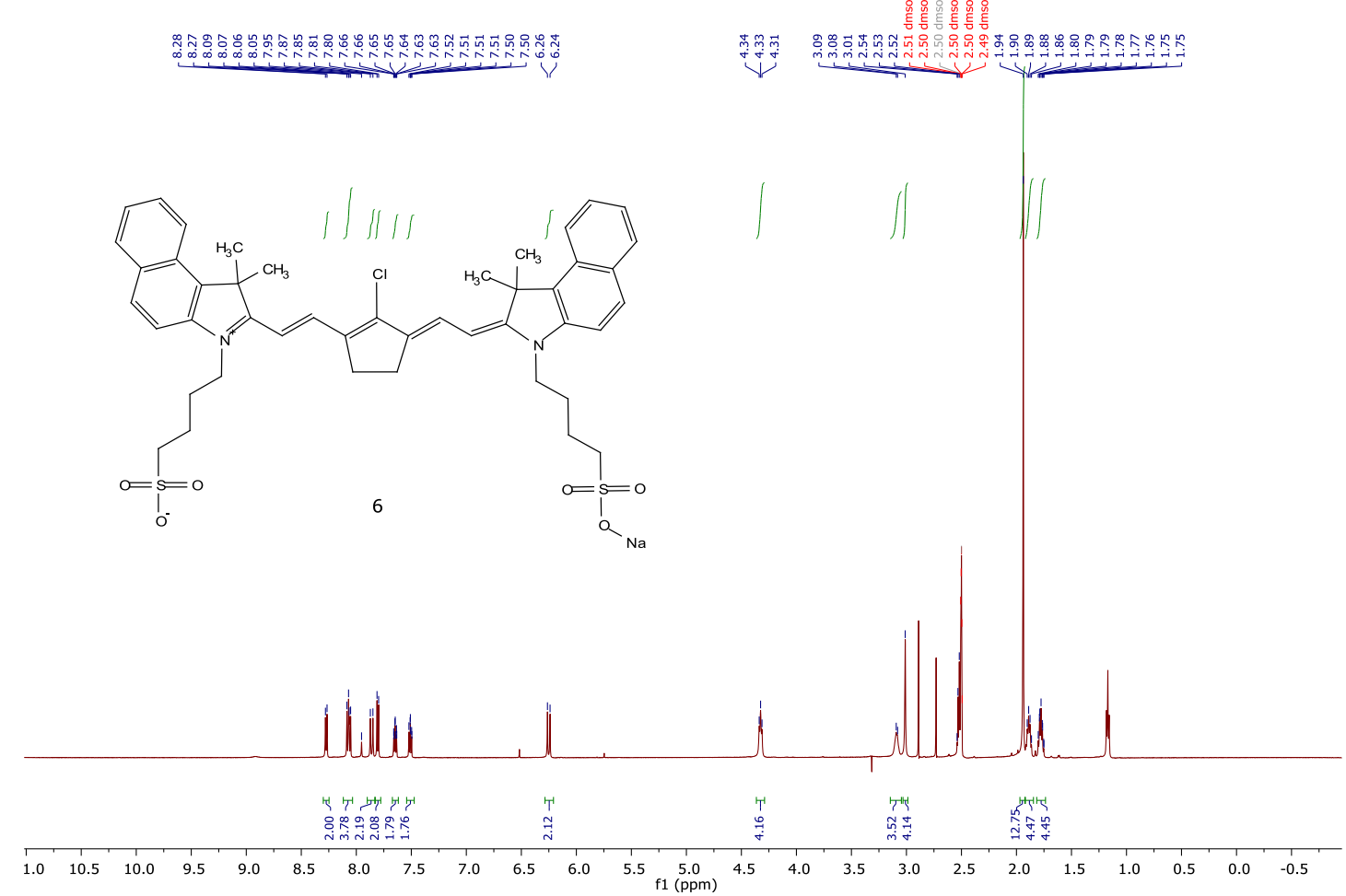

Figure S2. ${ }^{1} \mathrm{H}$ NMR spectrum of $\mathbf{6}\left(\mathrm{DMSO}-\mathrm{d}_{6}\right)$. Characteristic proton chemical shifts: Aromatic and vinylene (6.3$8.3 \mathrm{ppm}, 16 \mathrm{H})$, methylene groups in cyclopentene and sulfonate alkyl chain* $(1.8-1.9,3.0,3.1,4.3 \mathrm{ppm}, 20 \mathrm{H})$, methyl $(1.94 \mathrm{ppm}, 12 \mathrm{H})$. *Note: methyl group near ammonium nitrogen in indole heterocycle observed in spectra.
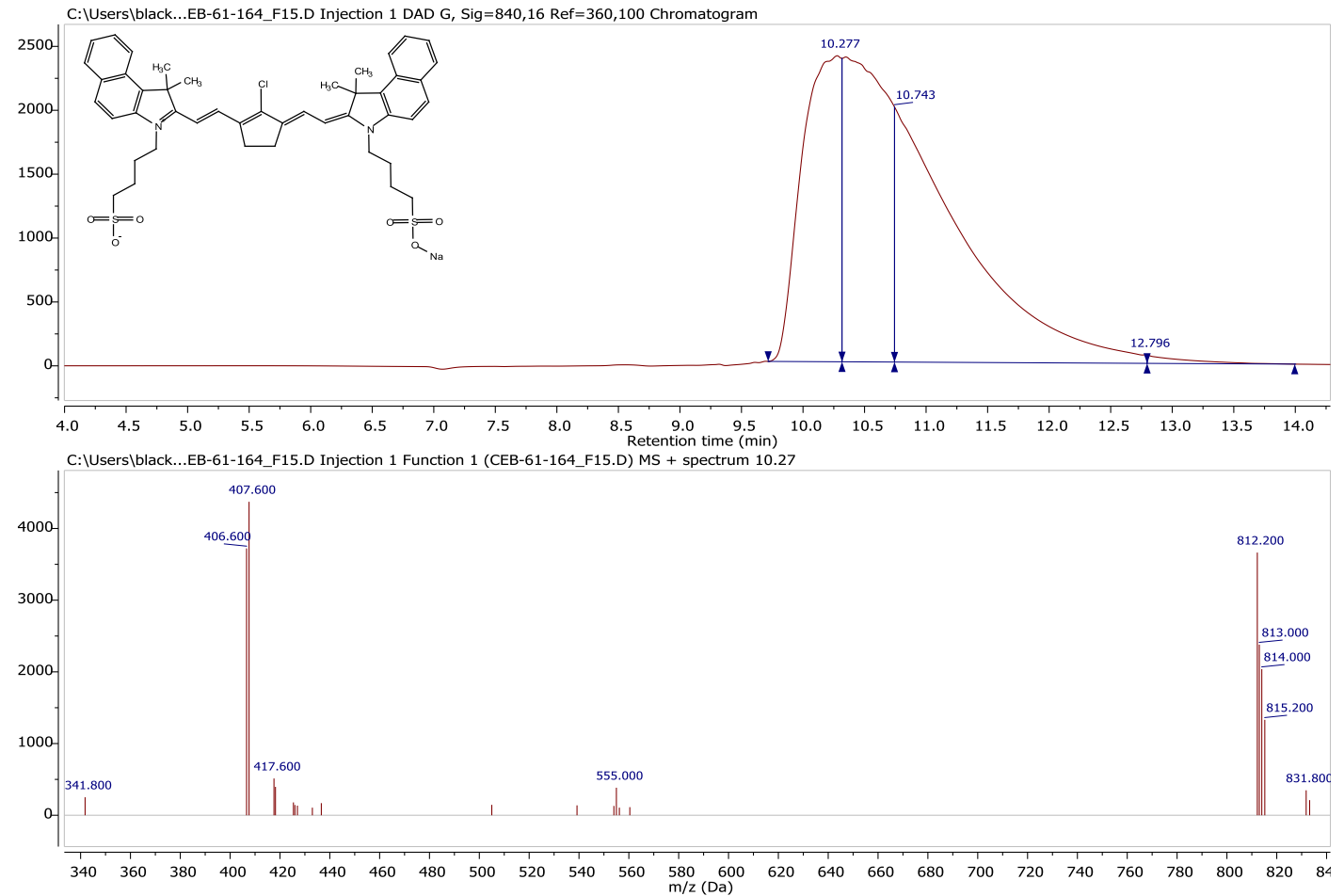

Figure S3. LC-MS data of pure 6 (IR-844), $\lambda_{\max }=844 \mathrm{~nm}$. Top: Chromatogram at $840 \mathrm{~nm}$ with pure 6 at $\mathrm{T}_{\text {ret }}=10.3$ minutes. Bottom: MS in positive mode with 6 seen at 812.2 [MW without $\mathrm{Na}^{+}$ion: $811.26 \mathrm{~g} / \mathrm{mol}$ ]. 

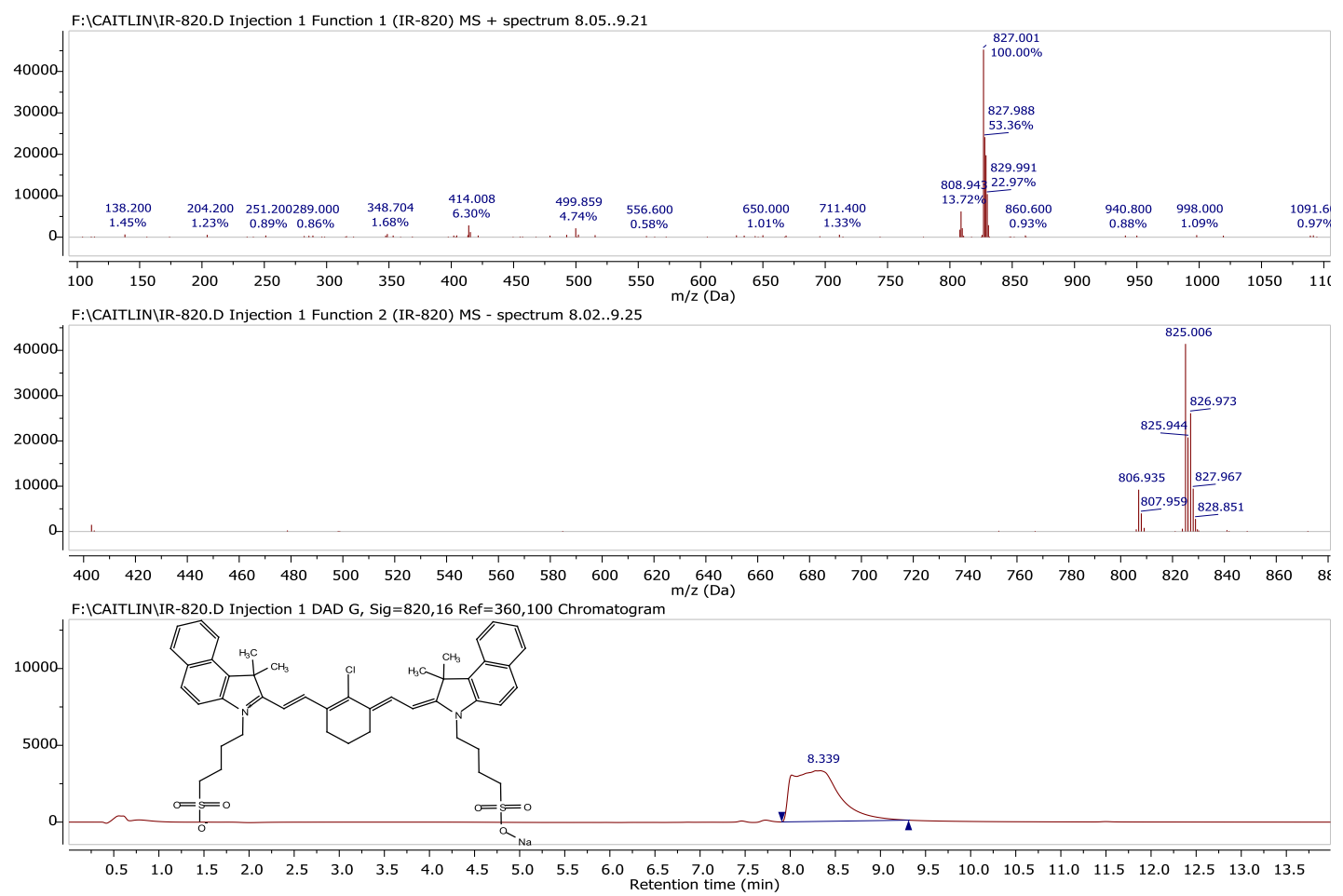

Figure S4. LC-MS data of 7, $\lambda_{\max }=820 \mathrm{~nm}$. Top: MS in positive mode with 7 seen at 827.0 [MW without $\mathrm{Na}^{+}$ion: $826.5 \mathrm{~g} / \mathrm{mol}$. Middle: MS in negative mode with 7 seen at 825.0. Bottom: Chromatogram at $820 \mathrm{~nm}$ with pure 7 at $\mathrm{T}_{\text {ret }}=8.0-8.9$ minutes.
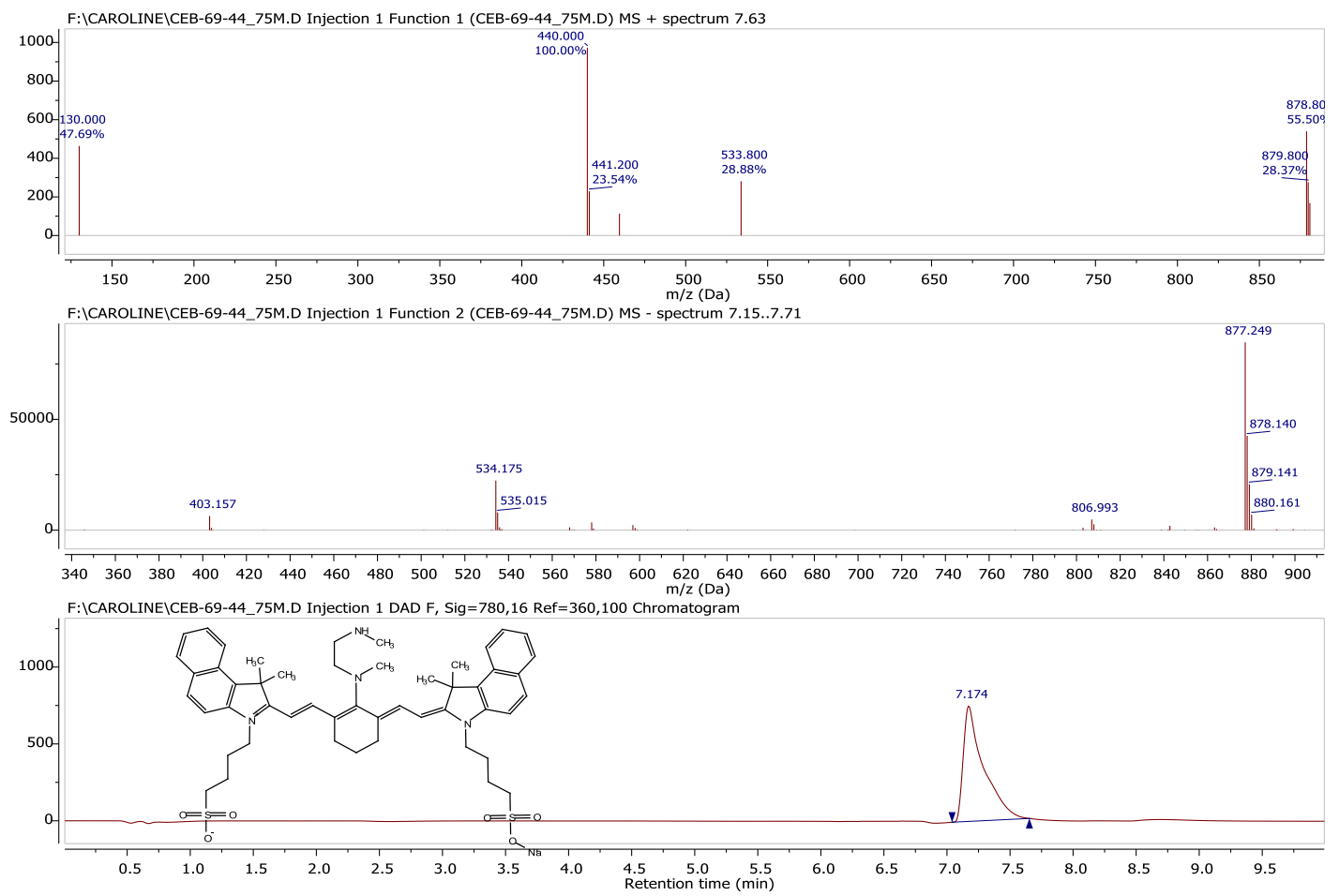

Figure S5. LC-MS data of $8, \lambda_{\max }=778 \mathrm{~nm}$. Top: MS in positive mode with 8 at 878.8 and $440.0((\mathrm{MW}+2) / 2)$ [MW without $\mathrm{Na}^{+}$ion: $878.2 \mathrm{~g} / \mathrm{mol}$. Middle: $\mathrm{MS}$ in negative mode with 8 at 877.2. Bottom: Chromatogram at $780 \mathrm{~nm}$ with 8 at $\mathrm{T}_{\mathrm{ret}}=7.2$ minutes. 

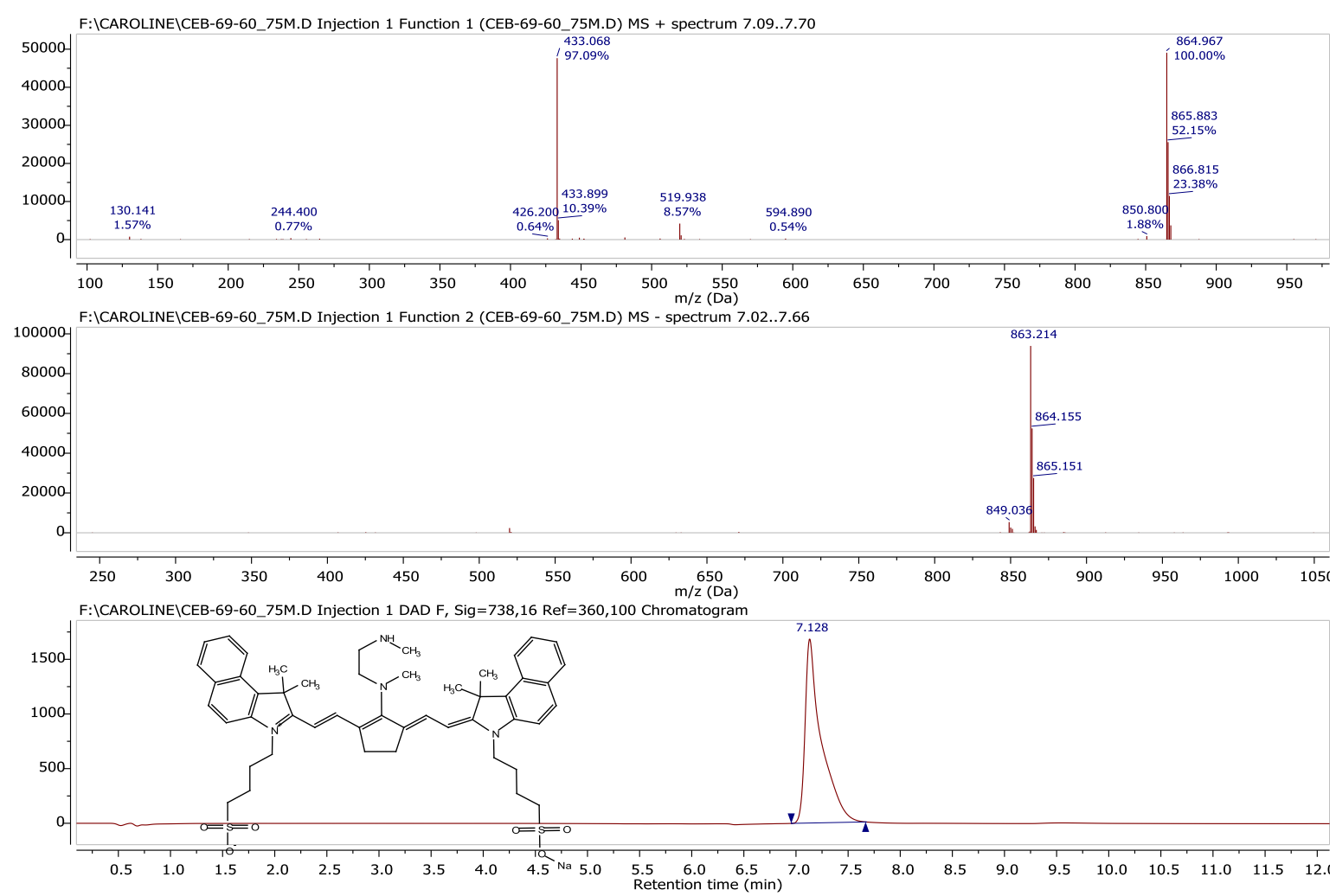

Figure S6. LC-MS data of pure 9, $\lambda_{\max }=738 \mathrm{~nm}$. Top: MS in positive mode with $\mathbf{9}$ seen at 865.0 and 433.1 $((\mathrm{MW}+2) / 2)$ [MW without $\mathrm{Na}^{+}$ion: $\left.864.2 \mathrm{~g} / \mathrm{mol}\right]$. Middle: $\mathrm{MS}$ in negative mode with 9 seen at 863.2. Bottom: Chromatogram at $738 \mathrm{~nm}$ with pure 9 at $\mathrm{T}_{\text {ret }}=7.1$ minutes. 

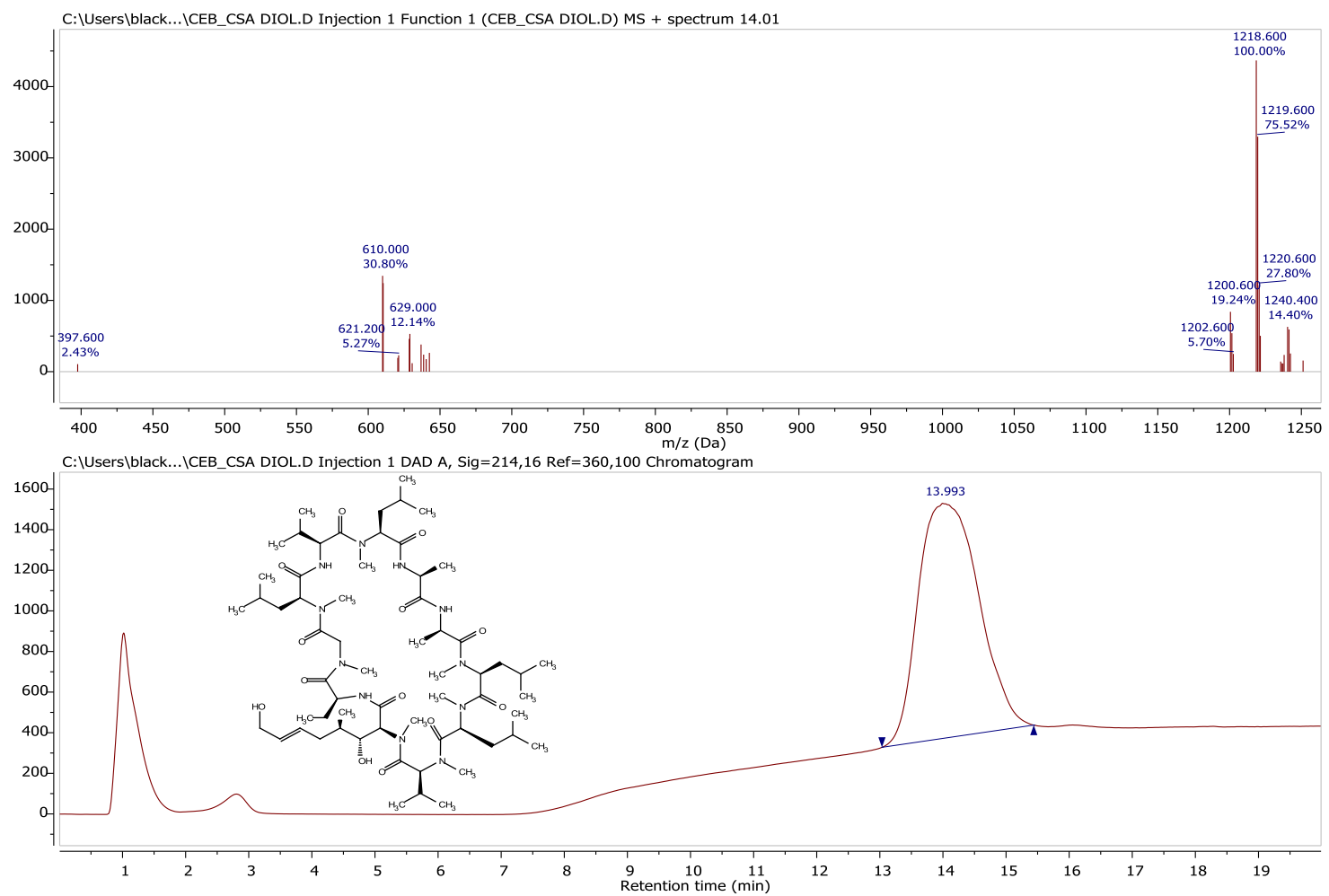

Figure S7. LC-MS data of 2, $\lambda_{\max }=214 \mathrm{~nm}$. Top: MS in positive mode with 2 seen at 1218.6 and $610.0((\mathrm{MW}+2) / 2)$ [MW: $1217.8 \mathrm{~g} / \mathrm{mol}]$. Bottom: Chromatogram at $214 \mathrm{~nm}$ with 2 at $\mathrm{T}_{\text {ret }}=13.9$ minutes.
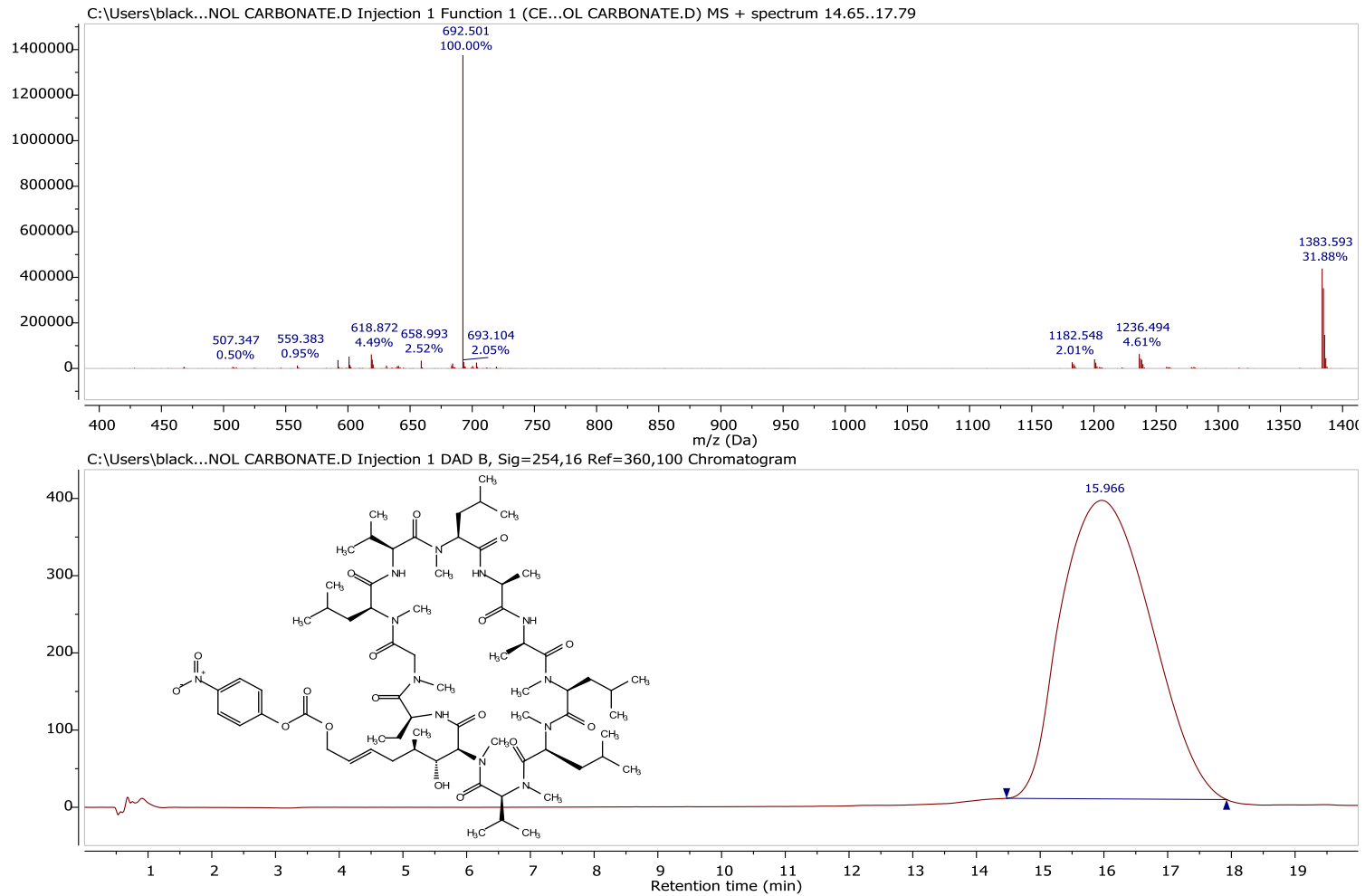

Figure S8. LC-MS data of 12, $\lambda_{\max }=214 / 254 \mathrm{~nm}$. Top: MS in positive mode with $\mathbf{1 2}$ seen at 1383.6 and 692.5 $((\mathrm{MW}+2) / 2)$ [MW: $1383.7 \mathrm{~g} / \mathrm{mol}]$. Bottom: Chromatogram at $254 \mathrm{~nm}$ with 12 at $\mathrm{T}_{\text {ret }}=15.97$ minutes. 


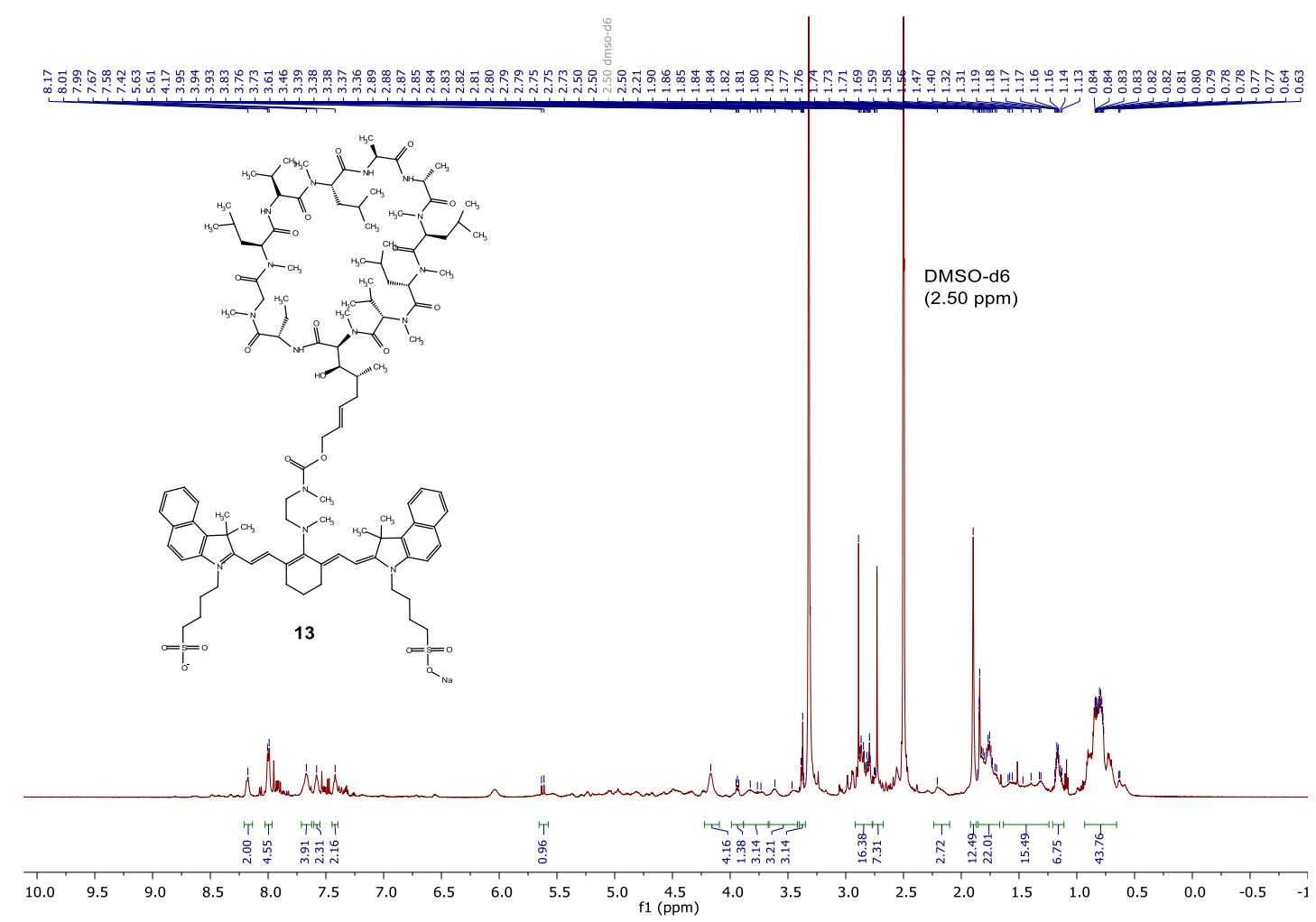

Figure S9. ${ }^{1} \mathrm{H}$ NMR spectrum of 13. Characteristic proton chemical shifts: Cyanine aromatic and vinylene (16H), methylene groups in cyclohexene and sulfonate alkyl chain $(22 \mathrm{H})$, cyanine methyl $(12 \mathrm{H})$, dimethylethylenediamine linker $(10 \mathrm{H})$, CsA diol (110H, not all observed).

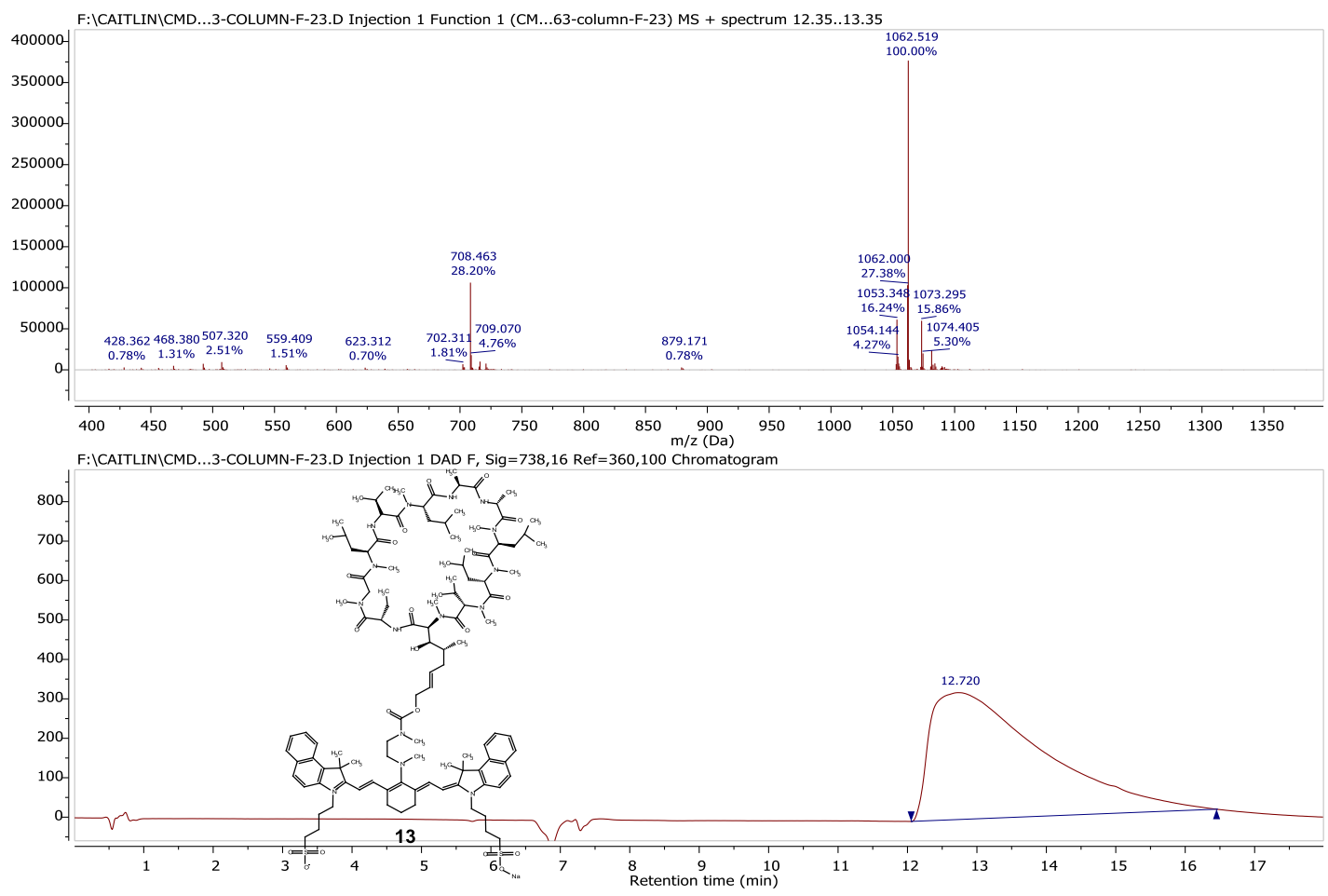

Figure S10. LC-MS data of 13, $\lambda_{\max }=738 \mathrm{~nm}$. Top: MS in positive mode with 13 seen at $1062.5((\mathrm{MW}+2) / 2)$ [MW: $2145.8 \mathrm{~g} / \mathrm{mol}$ ]. Bottom: Chromatogram at $738 \mathrm{~nm}$ with 13 at $\mathrm{T}_{\text {ret }}=12.7$ minutes. 


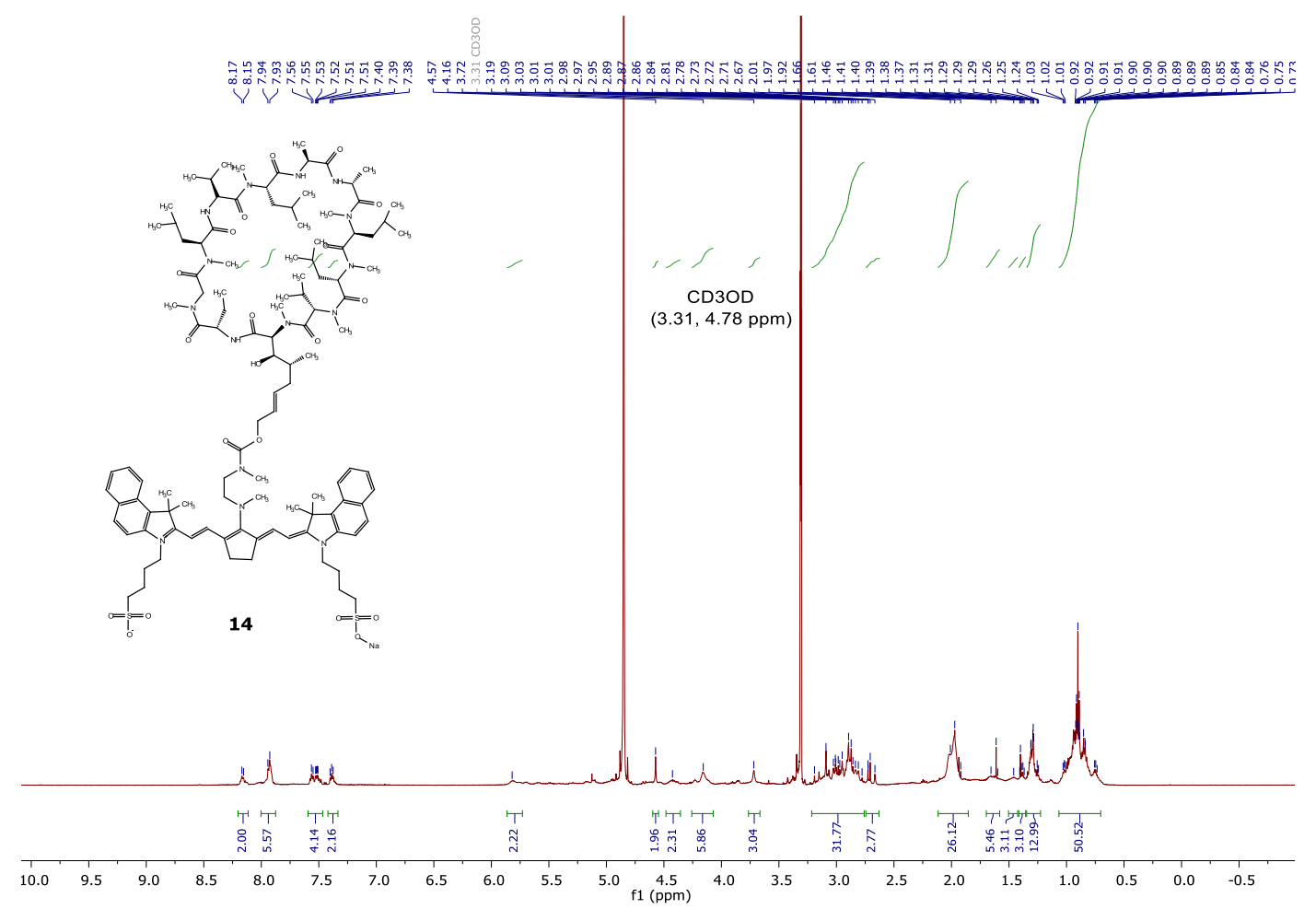

Figure S11. ${ }^{1} \mathrm{H}$ NMR spectrum of 14. Characteristic proton chemical shifts: Cyanine aromatic and vinylene (16H), methylene groups in cyclopentene and sulfonate alkyl chain $(20 \mathrm{H})$, cyanine methyl $(12 \mathrm{H})$, dimethylethylenediamine linker $(10 \mathrm{H})$, CsA diol $(110 \mathrm{H}$, not all observed).
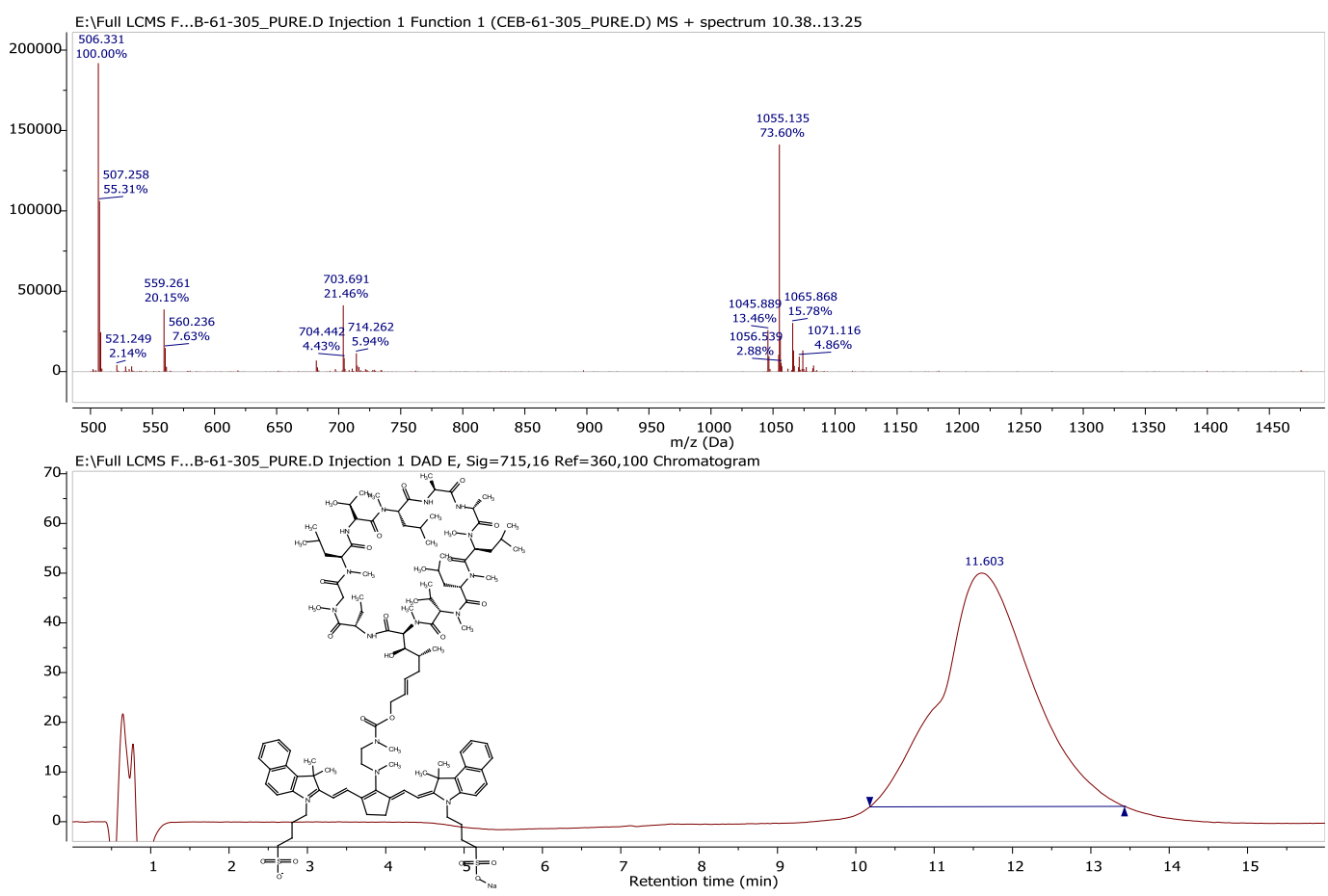

Figure S12. LC-MS data of 14, $\lambda_{\max }=705 \mathrm{~nm}$. Top: MS in positive mode with 14 seen at $1055.1((\mathrm{MW}+2) / 2)$ [MW: $2131.8 \mathrm{~g} / \mathrm{mol}$ ]. Bottom: Chromatogram at $715 \mathrm{~nm}$ with $\mathbf{1 4}$ at $\mathrm{T}_{\mathrm{ret}}=11.6$ minutes. 


\section{UV-Vis Spectra}

Table S2. Maximum absorption wavelengths of compounds $6-9$ and $13-14$.

\begin{tabular}{|c|c|c|c|}
\hline Compound & Absorbance, $\boldsymbol{\lambda}_{\max }(\mathbf{n m})$ & Compound & Absorbance, $\boldsymbol{\lambda}_{\max }(\mathbf{n m})$ \\
\hline $\mathbf{6}$ & 844 & $\mathbf{9}$ & 738 \\
\hline $\mathbf{7}$ & 820 & $\mathbf{1 3}$ & 738 \\
\hline $\mathbf{8}$ & 770 & $\mathbf{1 4}$ & 705 \\
\hline
\end{tabular}

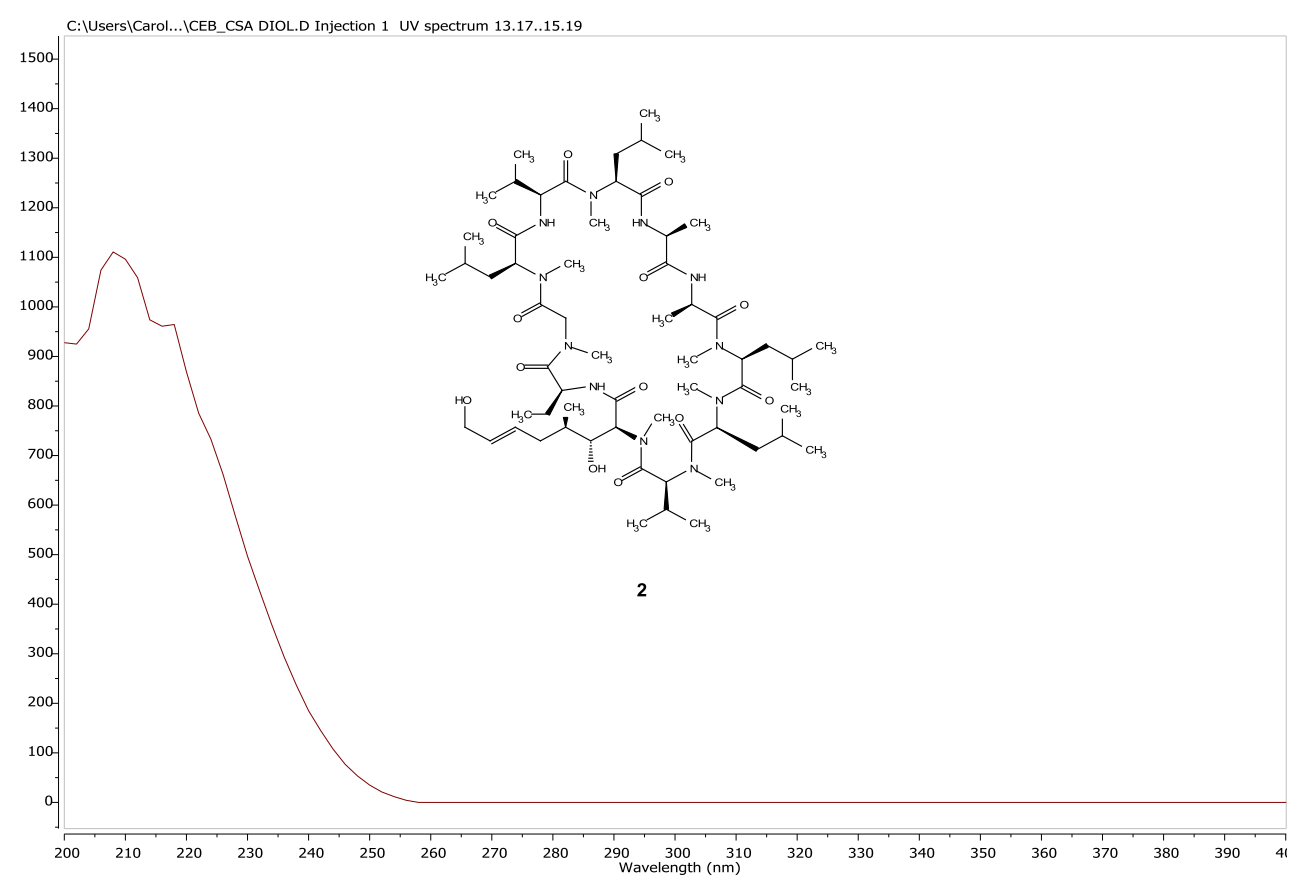

Figure S13. UV-Vis spectrum of Cyclosporine A diol 2.
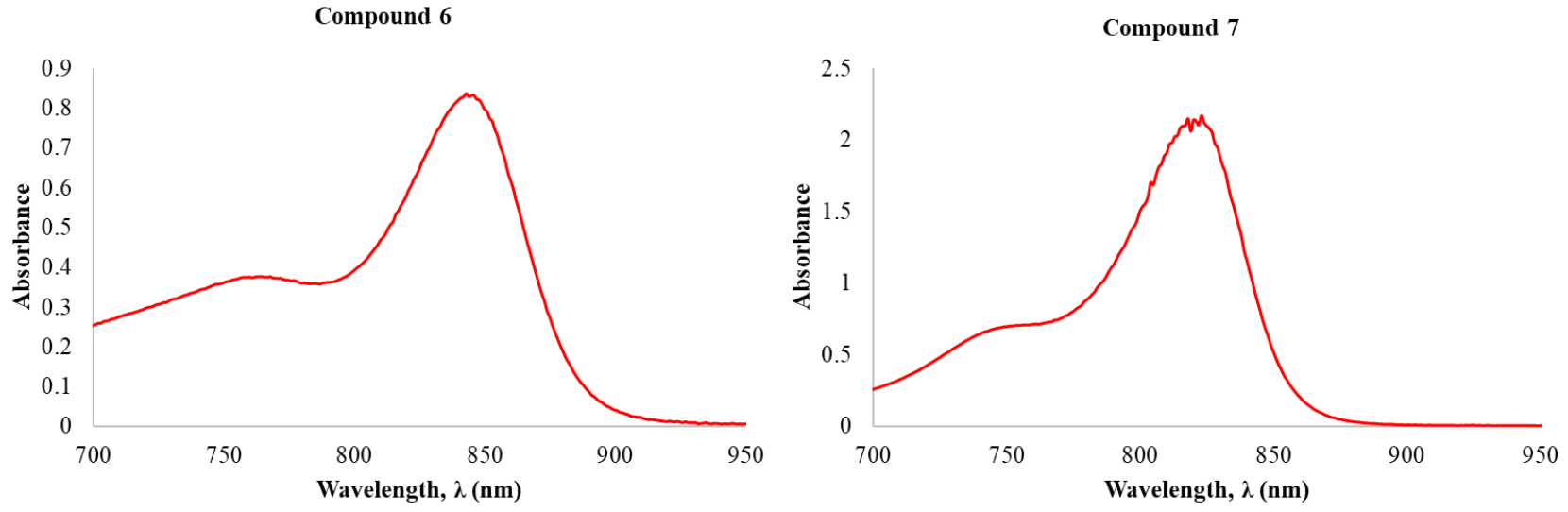

Figure S14. UV-Vis spectra of heptamethine cyanines 6 and 7. 


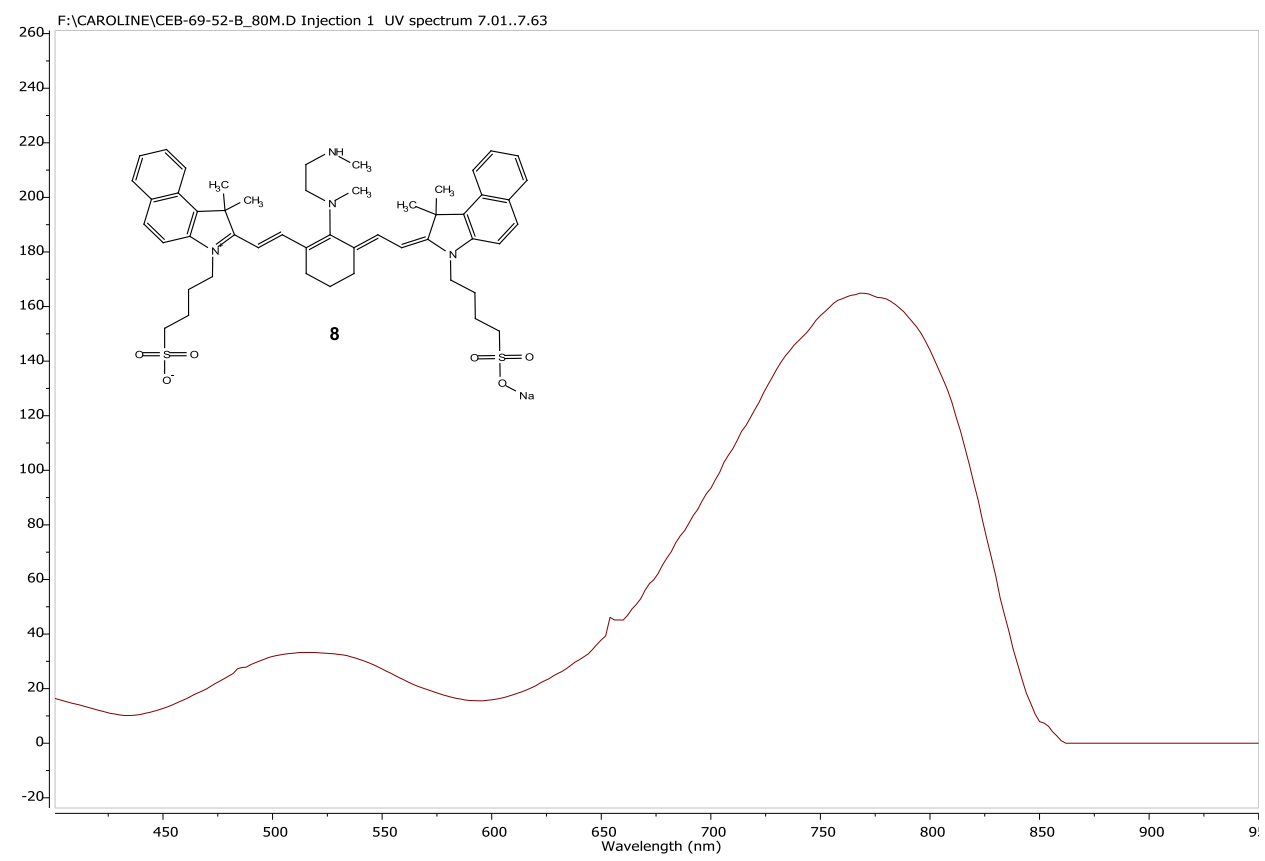

Figure S15. UV-Vis spectrum of 8.

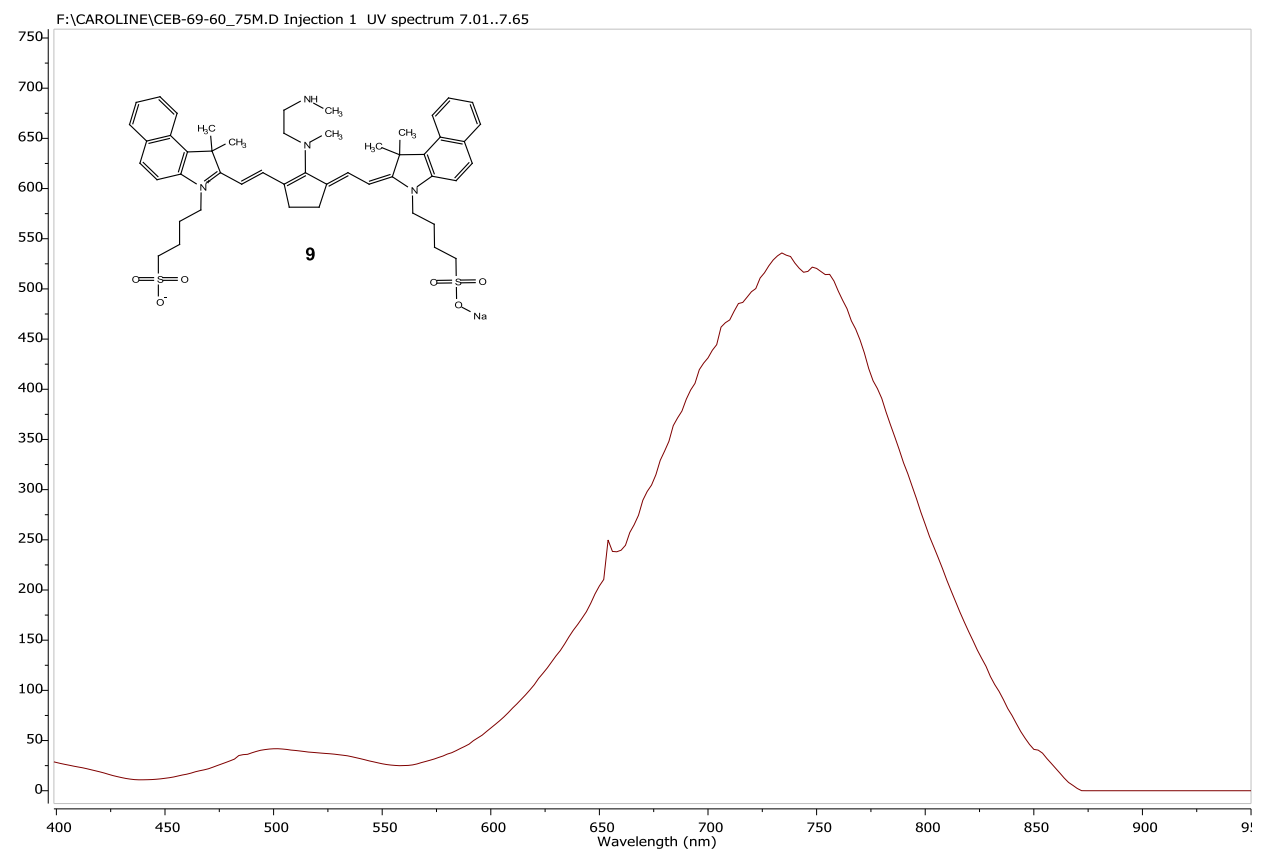

Figure S16. UV-Vis spectrum of 9. 


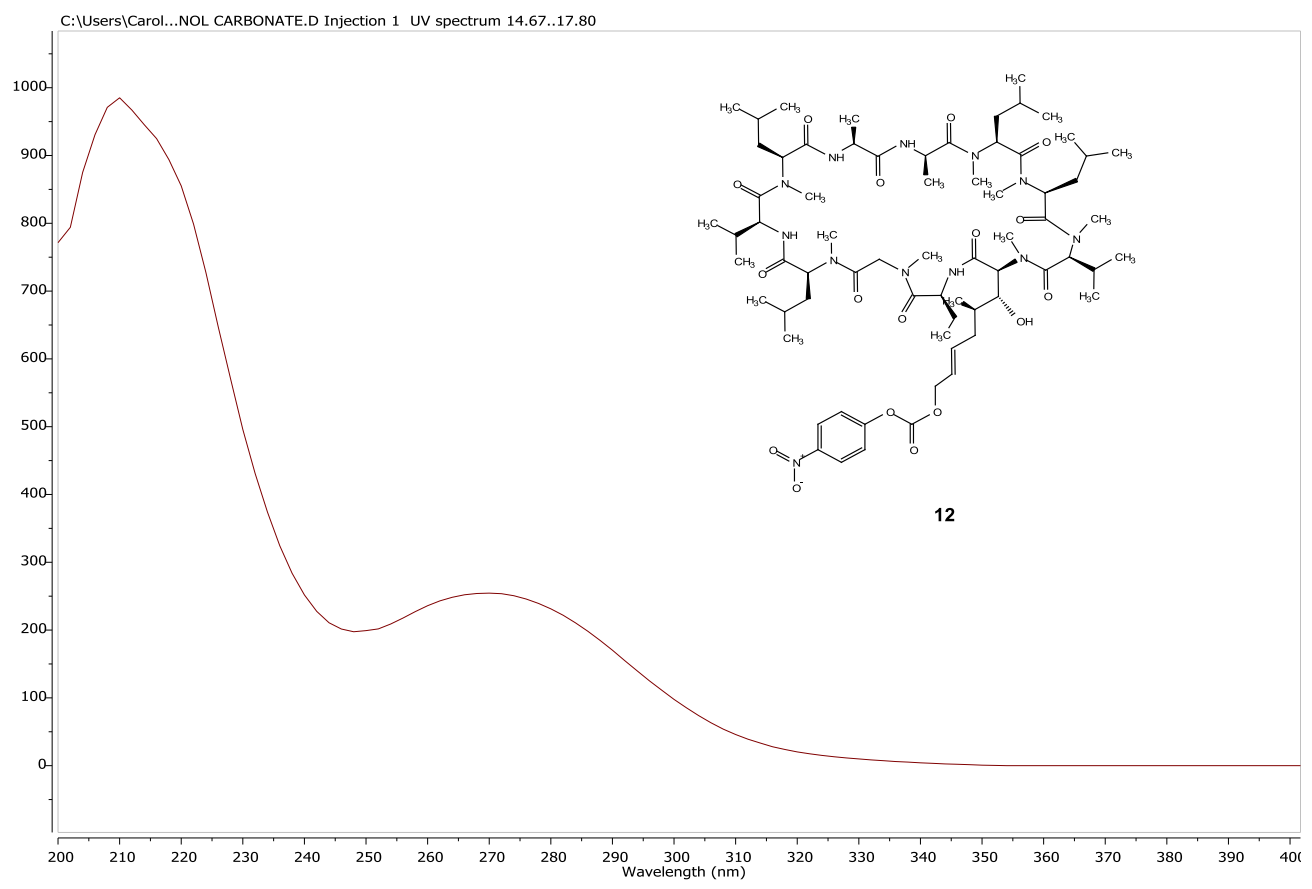

Figure S17. UV-Vis spectrum of activated Cyclosporine A diol-carbonate 12.

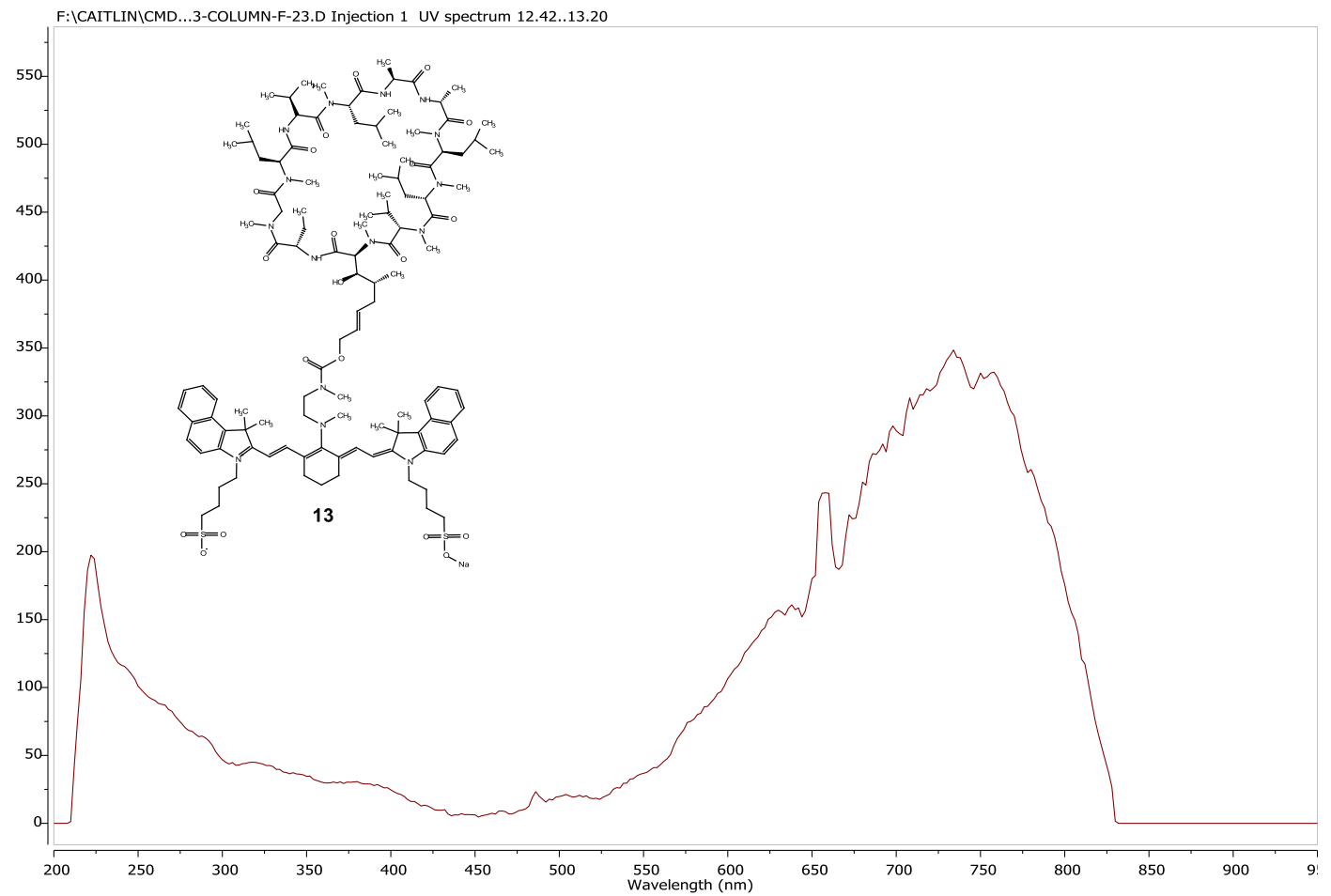

Figure S18. UV-Vis spectrum of cyanine-Cyclosporine A diol conjugate 13. 


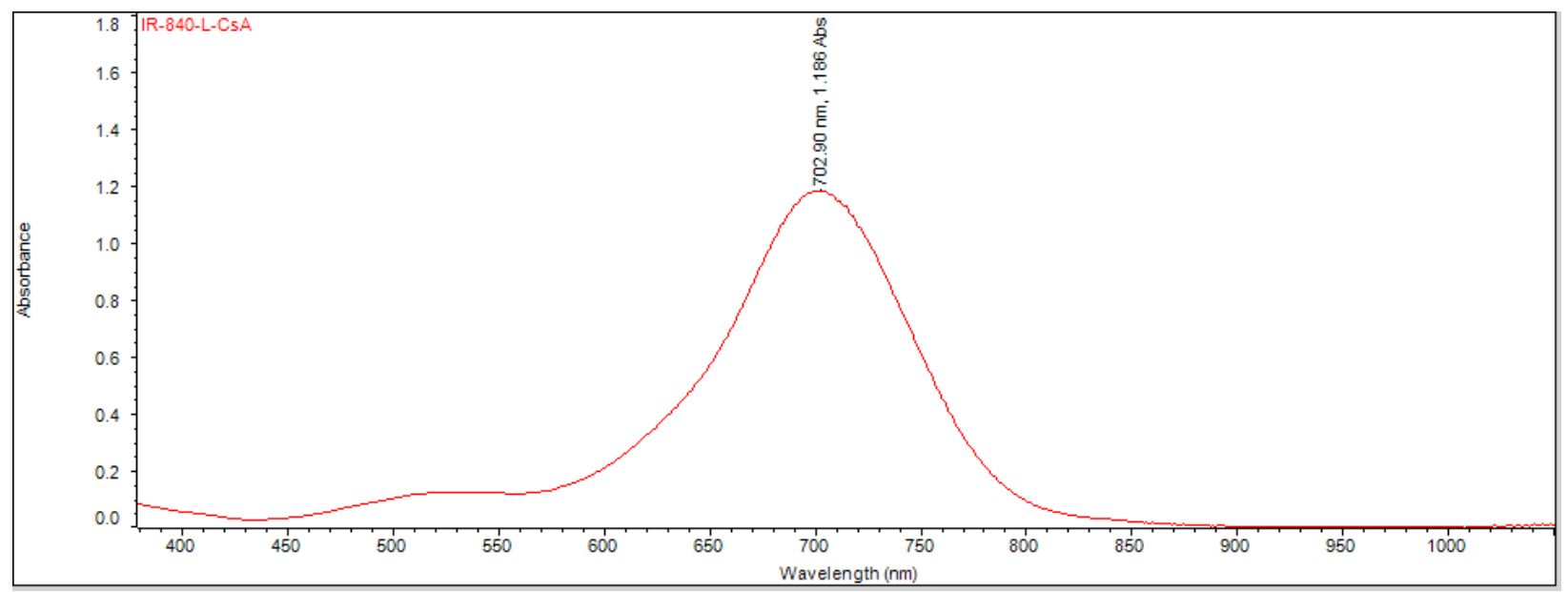

Figure S19. UV-Vis spectrum of cyanine-Cyclosporine A diol conjugate $\mathbf{1 4 .}$

\section{Determination of Molar Absorption Coefficients}

Molar absorption coefficients $(\varepsilon)$ were determined in methanol using Beer's law from graphs of absorbance vs. concentration $(\mathrm{n}=5)$. Measurements were performed in $10 \mathrm{~mm}$ path length quartz cuvettes at room temperature.

Table S3. Determination of molar absorption coefficients of cyanines 6 and 7 using UV-Vis standard curve data.

\begin{tabular}{|c|c|c|c|}
\hline Compound & $\boldsymbol{\varepsilon}$ & Line of Best Fit & $\mathbf{R}^{\mathbf{2}}$ \\
\hline $\mathbf{6}$ & 71,000 & $\mathrm{~A}=0.071 \mathrm{C}+0.084$ & 0.997 \\
\hline $\mathbf{7}$ & 204,000 & $\mathrm{~A}=0.204 \mathrm{C}+0.056$ & 1.000 \\
\hline
\end{tabular}

